\title{
MODEL INTEGRASI NILAI ISLAM DALAM PEMBELAJARAN SAINS
}

\author{
Azmah Marvavilha \\ nabilvilha@gmail.com \\ UIN Sunan Kalijaga Yogyakarta \\ Suparlan \\ suparlan@uny.ac.id \\ Universitas Negeri Yogyakarta
}

\begin{abstract}
ABSTRAK
Dalam konteks masa kini, agama dan sains memiliki relasi yang saling melengkapi, dapat didialogkan, dan didiskusikan. Dikotomi antara sains dan agama dapat diintegrasikan secara akurat, sehingga antara sains dan agama tidak berdiri sendiri-sendiri. Adanya integrasi antara sains dan agama, diharapkan akan menambah keyakinan dan semakin menyadari keagungan Allah swt. Dalam konteks pembelajaran sains, integrasi sains dan agama dapat dikategorikan dalam tiga konteks, yakni bayani, burhani, dan 'irfani. Bayani, sains diintegrasikan dengan teks Alquran. Burhani, sains diintegrasikan dengan konteks sosial, budaya, dan realitas alam. Irfani, sains diintegrasikan dengan manfaat dalam kehidupan sehari-hari. Dengan ketiga konteks tersebut, diharapkan pembelajaran akan semakin lebih bermakna.
\end{abstract}

Kata kunci: Integrasi, Nilai Islam, Pembelajaran, Sains

\begin{abstract}
In contemporary context, religion and science have a complementary relations, it can be dialogued and discussed. The dichotomy between science and religion can be accurately integrated, so that between science and religion does not stand alone. The existence of integration between science and religion, is expected to add confidence and be more aware of the majesty of Allah swt. In the context of science learning, the integration of science and religion can be categorized in three contexts, bayani, burhani, and 'irfani. Bayani, science is integrated with the text of the Alquran. Burhani, science is integrated with the social context, culture, and the reality of nature. Irfani, science is integrated with benefits in everyday life. With these three contexts, learning is expected to be more meaningful.
\end{abstract}

\section{PENDAHULUAN}

\begin{tabular}{llrr} 
Alquran & dan & Hadist & Nabi \\
memerintahkan & \multicolumn{2}{c}{ kita } & untuk \\
mengembangkan & ilmu & pengetahuan
\end{tabular}

dengan cara memikirkan penciptaan langit dan bumi menyuruh untuk berpikir, mengamati, dan meneliti alam semesta. Alquran juga memerintahkan 
kita sebagai manusia untuk menggali ilmu pengetahuan seluas-luasnya dengan melakukan penelitian-penelitian terhadap alam semesta.

Peran ilmuwan berdasar pesan Alquran adalah meneliti materi-materi, seperti fisika, biologi, kimia, dan fenomena alam lain dengan mengacu pada ayat-ayat Alquran. Sebagai mana para ilmuwan muslim pada masa kejayaan Islam disamping mereka menekuni alquran dan Hadis dengan menangkap pesan nilai sebagai petunjuk hidup, mereka juga memiliki semangat untuk meneliti alam semesta ciptaan Allah secara ilmiah sebagaimana yang dipesankan dalam alquran.

Dikotomi antara ilmu agama dan ilmu alam semesta dapat diintegrasikan dengan akurat, sehingga ilmu agama dan sains tidak berdiri sendiri-sendiri. Integrasi antara ilmu agama dengan sains sangat diperlukan, agar sains dan agama dapat mengantarkan pembacanya menyadari keagungan ilmu Allah swt. dan menumbuh jiwa yng yang tawaddu' lepas satu sama lain,

Upaya integrasi nilai karakter dalam pembelajaran semua mapel termasuk sains nampak dikuatkan melalui implementasi kurikulum 2013. Dimana pada kurikulum ini mulai muncul materi-materi ilmu sosial dan sains yang diintegrasikan dengan dimensi spiritual. Pada kompetensi inti no 1, yakni kompetensi spiritual, menunjukkan bahwa pegembang kurikulum menginginkan adanya integrasi dengan agama (spiritualnya) dalam setiap pembelajaran di kelas. Dengan tujuan, peserta didik sudah mengenal bahwa antara ilmu umum (lebih khususnya sains) tidak dapat dipisahkan dengan agama, dan nilai spiritual bisa ditumbuhkan melalui proses pembelajaran ilmu sosial dan sains.

Dalam kehidupan sehari-hari, ilmu sains, sering kita jumpai dalam kehidupan sehari-hari, diantaranya benda padat, benda cair, dan benda gas. Ketiga wujud benda tersebut sangat dekat dan mudah ditemukan oleh anak-anak. Pengenalan ketiga benda tersebut dapat dintegrasi baik secara bayani, burhani maupun irfani, dikarenakan sangat lekat dan sangat penting bagi kehidupan sehari-hari. Seperti halnya air, jika Allah tidak menciptakan air, maka kita tidak akan bisa melangsungkan kehidupan di bumi ini. Pengintegrasian tersebut juga dilakukan untuk anak-anak semakin bersyukur dengan apa saja yang telah diciptakan oleh Allah, dan anak-anak juga diharapkan untuk dapat berpikir 
secara kritis mengenai manfaat, serta dengan mengaitkan wujud benda dengan realitas sosial yang ada.

\section{HASIL DAN PEMBAHASAN}

\section{Benda Perspektif Sains}

Benda merupakan suatu yang dapat menempati ruang dan memiliki massa tertentu. Karena suatu benda juga mampu menempati suatu ruang, dan memiliki massa, sehingga disini akan diambil pandangan bahwa benda dan zat adalah sama.

\section{Wujud Benda}

Tiga keadaan umum dari suatu benda atau materi ada tiga, yakni padat, cair, dan gas. Ketiga keadaan tersebut, dapat dibedakan sebagai berikut (Aep Saefullah, 2014: 149-150):

1. Benda padat, memiliki sifat dan volume yang tetap. Ia akan mempertahankan bentuk dan ukurannya yang tetap. Misalkan tas, buku, pensil, dan sebagainya.

2. Benda cair, memiliki ciri-ciri sebagai berikut:

a.Benda cair tidak dapat mempertahankan bentuk yang tetap, melainkan ia mengambil bentuk tempat yang ditempatinya.

b. Volume tetap. Perubahan volume terjadi jika ia diberi gaya yang cukup besar.

c. Mengalir, yakni mengalir dari tempat yang lebih tinggi ke tempat yang lebih rendah karena adanya pengaruh gravitasi bumi.

d. Meresap Benda cair memiliki kemampuan untuk meresap melalui pori-pori kecil. Kemampuan tersebut disebut dengan daya kapilaritas. Contohnya adalah kompor minyak, minyak yang tersimpan di dalam tabung akan meresap ke atas melalui sumbu.

3. Benda Gas, ciri-cirinya yakni:

a. Tidak memiliki bentuk yang tetap. Bentuknya akan menyesuaikan dengan tempatnya. Misal gas yang berada di balon, akan memiliki bentuk sesuai dengan bentuk balon.

b. Dapat bergerak ke segala arah. Gas akan bergerak dari tempat yang suhunya tinggi ke tempat 
yang suhunya lebih rendah.

Misalnya angin darat dan angin

laut. Angin darat terjadi pada

malam hari ketika suhu daratan

tinggi dan suhu laut

rendahsehingga udara bergerak dari darat ke laut.

c. Volumenya berubah-ubah karena gas dapat memuai.

Karena benda cair dan gas tidak dapat mempertahankan bentuk yang tetap, dan keduanya memiliki kemampuan untuk mengalir, dengan demikian keduanya sering disebut dengan fluida. Fluida sendiri dibagi menjadi dua, yakni fluida statis dan fluida dinamis. Fluida statis, merupakan fluida yang adaa di dalam keadaan diam, tidak bergerak. Sementara itu, fluida dinamis, merupakan fluida yang bergerak.

\section{Perubahan Benda dan Perubahan Wujud Benda}

1. Perubahan Benda

Terdapat tiga perubahan benda, yakni (Aep Saefullah, 2014: 153):

a. Perubahan fisika, merupakan perubahan benda karena pengaruh fisik (lingkungan). Benda ini mengalami perubahan zat dan dapat kembali menjadi benda semula. Misalnya, lilin yang dibakar maka akan meleleh, dan lelehan lilin tersebut dapat dibentuk kembali menjadi lilin baru.

b. Perubahan kimia, merupakan perubahan benda yang disebabkan oleh pengaruh (reaksi) kimia. Benda tersebut akan menghasilkan zat baru dan tidak bisa kembali ke bentuk atau wujud semula. Misalnya, kayu yang dibakar berubah menjadi arang dan asap dan besi yang berkarat hingga habis oleh udara dan panas.

c. Perubahan biologi, merupakan perubahan suatu benda yang disebabkan oleh makhluk hidup (biologis). Makhluk itu biasanya berupa bakteri, jamur, dan lumut. Perubahan ini bersifat tetap, benda yang telah berubah tidak bisa kembali ke bentuk semula. Misalnya pelapukan tembok karena lumut.

2. Perubahan Wujud Benda

Setiap benda dapat berubah wujudnya menjadi gas, padat, maupun cair, tergantung pada proses yang dialaminya. Faktor yang 
mempengaruhi perubahan wujud suatu benda adalah suhu. Macammacam perubahan wujud benda, adalah (Aep Saefullah, 2014: 151152):

a. Mencair, perubahan wujud benda dari padat menjadi cair. Misalnya es batu yang mencair dalam gelas.

b. Membeku, perubahan wujud benda dari cair menjadi padat. Misalnya, air yang dimasukkan ke dalam lemari eslama-lama akan menjadi es batu.

c. Menguap, perubahan wujud benda dari cair menjadi benda gas. Misalnya, ketika menanak nasi, air yang ada dalam campuran beras dan air berubah karena dipanaskan.

d. Menyublim, perubahan wujud benda dari padat menjadi gas. Misalnya, kapur barus yang dipakai untuk mengharumkan lemari pakaian.

e. Mengembun, perubahan wujud benda dari uap menjadi air atau gas. Misalnya, titik-titik embun pagi di dedaunan, embun itu terbentuk dari gas yang dingin selama semalaman. f. Deposisi, perubahan wujud benda gas menjadi padat. Sering juga disebut dengan mengkristal contohnya adalah kristal-kristal salju yang terjadi karena udara yang sangat dingin.

\section{Kerapatan (Massa Jenis)}

Sebuah sifat penting yang dimiliki oleh suatu zat adalah rasio atau perbandingan massa terhadap volumenya. Ini yang dinamakan dengan kerapatan. Persamaan matematisnya, yakni:

$$
\text { Kerapatan }(\rho)=\frac{\text { Massa }}{\text { Volume }}=\frac{m}{v}
$$

Karena gram semula didefinisikan sebagai massa satu centimeter kubik air, maka kerapatan air dalam satuan cgs adalah $1 \mathrm{~g} / \mathrm{cm}^{3}$. Jika satuan tersebut diubah menjadi satuan SI, kilogram per meter kubik, maka kerapatan dari air adalah $10 \mathrm{~kg} / \mathrm{m}^{3}$ atau $1 \mathrm{~kg} / \mathrm{L}$.

Apabila kerapatan benda lebih besar daripada kepatan air, maka benda akan tenggelam di dalam air. Bila kerapatannya lebih kecil, maka bena akan mengapung. Pada saat mengapung, bagian volume sebuah benda yang tercelup dalam cairan manapun akan sama dengan rasio benda terhadap kerapatan cairan. Rasio atau perbandingan kerapatan sebuah zat 
dengan kerapatan air (massa jenis air) disebut dengan berat jenis zat itu. Berat jenis adalah bilangan tak terdefinisi yang sama dengan besarnya kerapatan ini bila dinyatakan dalam gram per centimeter kubik (atau dalam kilogram per liter.

Walaupun kebanyakan zat padat dan cairan mengembang sedikit bila dipanaskan dan menyusut sedikit bila dipengaruhi tekanan eksternal, perubahan dalam volume ini relatif kecil, oleh karena itu dapat dikatakan bahwa kerapatan kebanyakan zat padat dan cairan hampir tidak bergantung pada temperatur dan tekanan. Sebaliknya, kerapatan suatu gas sangat tergantung pada tekanan dan temperatur, sehingga temperatur dan tekanan harus dinyatakan jika akan memberikan kerapatan suatu gas (Tipler, 1998: 383-385). 
Tabel 1 Kerapatan Beberapa Zat

\begin{tabular}{|l|r|}
\hline \multicolumn{1}{|c|}{ Zat } & Kerapatan $\left(\mathrm{kg} / \mathrm{m}^{3}\right)$ \\
\hline Aluminium & $2,70 \times 10^{3}$ \\
\hline Tembaga & $8,93 \times 10^{3}$ \\
\hline Tanah & $5,52 \times 10^{3}$ \\
\hline Kaca (biasa) & $2,4-2,8 \times 10^{3}$ \\
\hline Emas & $19,3 \times 10^{3}$ \\
\hline Besi & $7,96 \times 10^{3}$ \\
\hline Air raksa & $13,6 \times 10^{3}$ \\
\hline Air laut & $1,025 \times 10^{3}$ \\
\hline Air & $1,00 \times 10^{3}$ \\
\hline Udara & 1,293 \\
\hline Helium & 0,1786 \\
\hline Hidrogen & 0,08994 \\
\hline Uap $\left(100{ }^{\circ} \mathrm{C}\right)$ & 0,6 \\
\hline
\end{tabular}

Dalam tabel 1, kerapatan diberikan pada kondisi standar (tekanan atmosfer pada ketinggian air laut dan temperatur 0 $\left.{ }^{\circ} \mathrm{C}\right)$. Berdasarkan tabel, kerapatan suatu gas sangat lebih kecil jika dibandingkan dengan kerapatan cairan atau zat padat. Dalam sistem satuan di Amerika seharihari, istilah kerapatan berat (rasio berat sebuah benda terhadap volumenya) seringkali digunakan. Kerapatan berat adalah hasil kali kerapatan $\rho$ dengan percepatan gravitasi $g$ :

$$
\rho g=\frac{w}{V}=\frac{m g}{V}
$$

Kerapatan berat air adalah $62,4 \mathrm{lb} / \mathrm{ft}^{3}$.

\section{Tekanan dalam Fluida}

Fluida berbeda dengan zat padat, yakni tidak dapat menopang tegangan geser. Jadi, fluida akan berubah bentuk untuk mengisi sebuah tabung dengan bentuk apapun. Bila sebuah benda tercelup ke dalam air, fluida akan mengadakan sebuah gaya yang tegak lurus permukaan benda di setiap titik pada permukaan. Jika benda cukup kecil, sehingga kita dapat mengabaikan tiap perbedaan kedalaman fluida, gaya per satuan luas yang diadakan oleh fluida akan sama di setiap titik pada permukaan benda.

Gaya per satuan luas inilah yang dinamakan dengan tekanan fluida $P$.

$$
P=\frac{F}{A}
$$

Satuan SI untuk tekanan adalah newton per meter persegi $\left(\mathrm{N} / \mathrm{m}^{2}\right)$, dan disebut dengan pascal (pa), dengan $1 \mathrm{pa}$ $=1 \mathrm{~N} / \mathrm{m}^{2}$. Satuan tekanan lain yang biasa digunakan adalah atmosfer (atm), 
yang mendekati tekanan udara pada ketinggian laut (Tipler, 1998: 389).

Jika gaya $F$ tidak tegak lurus pada bidang tekan, maka yang menjadi gaya tekan adalah komponen gaya $F$, yaitu $F \cos \theta$, arahnya tegak lurus dengan bidang tekan, sehingga tekanan dituliskan sebagai berikut:

$P=\frac{F \cos \theta}{A}$

dengan $\theta$ adalah sudut antara vektor gaya $F$ dan garis normal (garis yang tegak lurus bidang) (Mulyatno, 2014:

$$
\text { 3.18-3.19). }
$$

Tekanan yang disebabkan fluida yang menekan sebuah benda cenderung menekan benda itu. Rasio tekanan terhadap penurunan fraksional dalam volume $(-\Delta \mathrm{V} / \mathrm{V})$ dinamakan modulus limbak (Bulk Modulus)

$$
B=-\frac{P}{\Delta V / V}
$$

Karena semua bahan akan berkurang volumenya ketika dibeli tekanan eksternal, maka sebuah tanda minus diberikan pada persamaan 6.3 untuk membuat $B$ positif. Tekanan yang diadakan fluida ekuivalen dengan tegangan kompresi, dan penurunan fraksional dalam volume $(-\Delta \mathrm{V} / \mathrm{V})$ adalah regangan kompresi. Invers modulus limbak dinamakan dengan kompresibilitas

$k=\frac{1}{B}=\frac{-\Delta V / V}{P}$

Makin sulit bahan ditekan, maka makin kecil perubahan fraksional $\Delta \mathrm{V} / \mathrm{V}$ untuk suatu tekanan, dengan demikian, makin kecil kompresibilitas $k$. Konsep dari modulus limbak dan kompresibilitas berlaku untuk zat cair dan gas, juga berlaku pada zat padat. Zat padat dan zat cair relatif tak kompresibel, yang artinya mempunyai nilai kompresibilitas yang kecil dan nilai modulus limbak yang besar. Nilai ini juga relatif tidak bergantung pada temperatur dan tekanan (Tipler, 1998: 390).

Tekanan di danau atau di lautan bertambah dengan bertambahnya kedalaman. Demikian pula, tekanan atmosfer akan berkurang bila ketinggian bertambah. Untuk cairan seperti air yang kerapatannya konstan dimanamana, tekanan akan bertambah secara linier dengan kedalaman. Hal tersebut dapat secara mudah diperlihatkan dengan memperhatikan kolom cairan setinggi $h$ dengan luas penampang $A$. Tekanan di dasar kolom harus lebih besar dari tekanan di bagian atas kolom untuk menopang berat kolom. Massa kolom cairan ini adalah: 


$$
m=\rho V=\rho A h
$$

dan beratnya adalah:

$$
w=m g=\rho A h g
$$

Jika $P_{o}$ adalah tekanan di bagian atas dan $P$ adalah tekanan di dasar, maka gaya neto ke atas yang disebabkan oleh beda tekanan ini adalah $P A-P_{o} A$. Dengan membuat gaya ke atasneto ini sama dengan berat kolom, maka diperoleh:

$$
P A-P_{o} A=\rho A g h
$$

atau

$$
P=P_{o}+\rho g h(\rho \text { konstan })
$$

Kenyataan bahwa tekanan pada kedalaman $h$ lebih besar daripada tekanan di bagian atas sejumlah $\rho g h$ berlaku untuk cairan dalam bejana apapun, tak tergantung pada bentuk bejana. Selanjutnya, tekanan adalah sama di setiap titik pada kedalaman yang sama. Jadi, jika kita menambah $P_{o}$, misalnya, dengan menekan ke bawah bagian atas permukaan dengan sebuah pengisap, maka pertambahan tekanan adalah sama dimana-mana dalam cairan. Hal ini dikenal dengan prinsip pascal, yang ditemukan oleh Blaise Pascal. Bunyi dari prinsip pascal adalah “Tekanan yang diberikan pada suatu cairan yang tertutup diteruskan tanpa berkurang ke tiap titik dalam fluida dan ke dinding bejana.” (Tipler, 1998: 390391)

Tekanan yang disebabkan zat cair pada kedalaman $h$ disebabkan oleh berat kolom zat cair di atasnya. Dengan demikian gaya yang bekerja pada luas daerah tersebut adalah $F=m g=\rho A h g$, dimana $A h$ adalah volume kolom, $\rho$ adalah massa jenis air (dianggap konstan), dan $g$ adalah percepatan gravitasi. Tekanan, dengan demikian dapat dituliskan menjadi:

$$
P=\frac{F}{A}=\frac{\rho A h g}{A},
$$

$$
P=\rho g h
$$

Dengan demikian, tekanan berbanding lurus dengan massa jenis air, dan dengan kedalaman dari zat cair tersebut. Pada umumnya, tekanan pada kedalaman yang sama dalam zat cair yang serba sama adalah sama (Giancoli, 1999: 327).

\section{Gaya Apung ke Atas dan Prinsip Archimedes}

Benda-benda yang dimasukkan pada zat cair tampaknya memiliki berat yang lebih kecil daripada saat berada di luar air tersebut. Misalnya, sebuah batu yang besar mungkin akan sulit diangkat 
dari tanah, dan seringkali dapat diangkat lebih mudah dari dasar sungai. Ketika batu menimpa permukaan air, tampaknya tiba-tiba menjadi jauh lebih berat. Banyak benda, seperti kayu, yang mengapung di atas air. Ini adalah contoh pengapungan. Gaya apung ke atas dilakukan oleh zat cair tersebut (Giancoli, 1999: 299).

Gaya apung tergantung pada kerapatan fluida dan volume benda, tetapi tidak pada komposisi atau bentuk benda, dan besarnya sama dengan berat fluida yang dipindahkan oleh benda. Adapun bunyi dari prinsip Archimedes, yaitu "Sebuah benda yang tenggelam seluruhnya atau sebagian dalam suatu fluida diangkat ke atas oleh sebuah gaya yang sama dengan berat fluida yang dipindahkan." Archimedes, menemukan cara yang teliti dan mudah untuk menentukan berat jenis dari suatu mahkota Raja Hieron II, yang kemudian ia bandingkan dengan berat jenis emas. Berat jenis sebuah benda adalah berat benda di udara dibagi dengan berat air yang volumenya sama:

Berat jenis $=\frac{\text { berat benda di udara }}{\text { berat air dengan volume yang sama }}$

Akan tetapi, menurut prinsip Archimedes, berat air yang sama volumenya sama dengan gaya apung pada benda ketika tenggelam. Karena itu sama dengan hilangnya berat benda bila ia ditimbang ketika tenggelam di dalam air. Jadi,

Berat jenis $=\frac{\text { berat benda di udara }}{\text { berat yang hilang bila tenggelam di air }}(9)$

Jika suatu benda berada di dalam fluida maka ada volume zat cair yang dipindahkan sebesar volume bagian benda yang berada di dalam zat cair. Jika volume fluidayang dipindahkan besarnya $V$ dan kerapatan massa fluida (massa per satuan volume) adalah $\rho$, maka besarnya massa fluida yang dipindahkan adalah:

$$
m=\rho V
$$

dan berat fluida yang dipindahkan adalah,

$$
w_{F}=m g=\rho V g
$$

Menurut prinsip Archimedes, besarnya gaya tekan ke atas adalah,

$$
F_{b}=w_{F}=\rho V g
$$

dengan $F_{b}$ adalah gaya tekan ke atas.

Jika benda memiliki kerapatan massa $\rho_{1}$ dan fluida mempunyai kerapatan $\rho_{2}$, maka perbandingan antara berat benda dan gaya tekan ke atas dapat dinyatakan sebagai (Mulyatno, 2014: 3.27), 


$$
\frac{w}{F_{b}}=\frac{\rho_{1} V g}{\rho_{2} V g}=\frac{\rho_{1}}{\rho_{2}}
$$

\section{Model Integrasi Nilai dalam Pembelajaran Sains}

\section{Integrasi dalam Konteks Bayani}

Integrasi dalam konteks bayani maksudnya berupaya untuk memperjelas, mengungkap, dan menuangkan maksud pembicaraan dengan berdasarkan lafadz. Ciri utamanya adalah menggunakan teks sebagai rujukan pokok sumber pengetahuan (Suyudi, 2005: 152). Pada artikel ini, teks yang diambil adalah nash Alquran atau ayat-ayat Alquran. Dalam Alquran, terdapat banyak ayat-ayat Alquran yang menjelaskan dan membuktikan adanya sains, termasuk pada materi wujud benda.

Terdapat banyak ayat yang membuktikan adanya wujud benda tersebut. Salah satu contoh dari benda cair yaitu Air. Allah menyebut kata air (maa') dalam Alquran sebanyak 33 kali dalam bentuk nakirah dan 16 kali dalam bentuk ma'rifah (Nadiah, 2013: 514). Firman Allah dalam surat al-Mu'minun ayat 18, yang berbunyi:

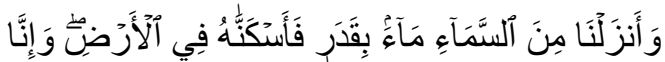

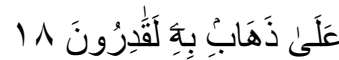

Artinya: Dan Kami turunkan air dari langit menurut suatu ukuran; lalu Kami jadikan air itu menetap di bumi, dan sesungguhnya Kami benar-benar berkuasa menghilangkannya. (QS. AlMu'minun: 18)

Ayat di atas mengisyaratkan bahwa air hujan yang turun dari langit akan tersimpan sebagiannya di dalam perut bumi agar air tersebut tidak hilang, lalu air tersebut keluar lagi ke atas permukaan dalam bentuk sumber-sumber air dan sungai-sungai yang mengalir hingga ke laut (Nadiah, 2013: 505). Hal tersebut sesuai dengan salah satu sifat air, yakni air dapat mengalir.

Syaikh Ahmad Syakir, dalam kitabnya menafsirkan ayat di atas sebagai nikmat-nikmat yang telah Allah berikan kepada umatNya, yakni menurunkan hujan sesuai dengan ukurannya, yakni sesuai dengan kebutuhannya, tidak terlalu banyak. Karena jika terlalu banyak maka akan mengakibatkan kerusakan di bumi dan bangunan, dan Allah juga menurunkan air hujan tidak terlalu sedikit agar dapat mencukupi kebutuhan untuk pengairan, minuman, dan pemanfaatan lainnya. Makna “lalu Kami jadikan air itu menetap di bumi." Artinya, Allah telah menjadikan air itu kekal di dalam bumi jika sudah turun dari awan dan 
Allah telah menjadikan bumi sebagai peresapannya, sehingga bumi dapat meresapnya dan biji-bijian serta benih dapat tumbuh. Selanjutnya, makna dari "Dan pasti Kami berkuasa melenyapkannya." Artinya, jika Allah menghendaki hujan tidak turun, pasti Allah akan lakukan, dan jika hal tersebut terjadi maka kelangsungan hidup makhluk di muka bumi akan terancam punah (Ahmad Syakir, 2012: 716-717).

Hujan, seperti yang telah diketahui, juga merupakan salah satu contoh adanya perubahan wujud benda. Hujan terjadi karena adanya air laut yang menguap dan berubah menjadi awan di udara, lalu kembali lagi ke permukaan bumi dalam bentuk air hujan yang dapat diminum oleh manusia, hewan, dan tumbuhtumbuhan. Firman Allah dalam surat arRa'd ayat 17, yang berbunyi:

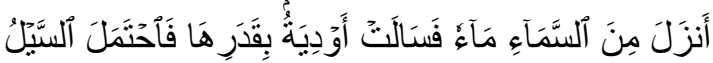

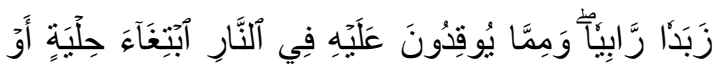

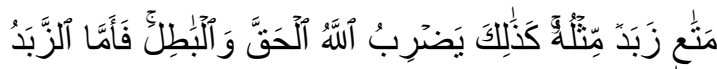

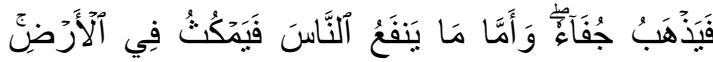

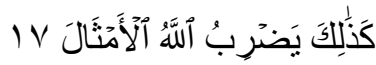

Artinya: Allah telah menurunkan air (hujan) dari langit, maka mengalirlah air di lembah-lembah menurut ukurannya, maka arus itu membawa buih yang mengambang. Dan dari apa (logam) yang mereka lebur dalam api untuk membuat perhiasan atau alat-alat, ada (pula) buihnya seperti buih arus itu. Demikianlah Allah membuat perumpamaan (bagi) yang benar dan yang bathil. Adapun buih itu, akan hilang sebagai sesuatu yang tak ada harganya; adapun yang memberi manfaat kepada manusia, maka ia tetap di bumi. Demikianlah Allah membuat perumpamaan-perumpamaan. (QS. Ar$R a$ 'd:17)

Ayat di atas menjelaskan tentang adanya hujan yang turun dari langit, dan kemudian mengalir ke lembah-lembah. Artinya, air tersebut selalu mengalir dari tempat yang tinggi menuju tempat yang rendah. Peristiwa hujan itu sendiri terjadi karena adanya uap air yang ada di udara yang terbentuk karena adanya penguapan karena terkena sinar matahari. Uap air juga bisa terbentuk dari udara yang dilepaskan oleh manusia. Uap air tersebut kemudian berkumpul di udara dalam bentuk yang tidak dapat dilihat oleh mata. Namun, ketika ketebalannya semakin meningkat akibat udara dingin, ia akan membentuk titik-titik air di sekitar partikel debu yang tergantung di udara hingga membentuk awan (bila berada jauh di atas permukaan bumi) atau kabut (bila terletak dekat dari permukaan bumi). 
Terkadang uap air tidak menebal meski udara dalam keadaan dingin, karena tidak adanya debu di udara. Dalam kondisi tersebut, uap air akan tetap berada di udara. Namun, ketika angin membawa debu ke tempat uap-uap air tersebut, uap air akan menebal membentuk awan. Jadi, anginlah yang membantu terbentuknya awan. Angin jugalah yang membantu proses "penyerbukan” awan sehingga berubah menjadi air hujan yang mengguyur ke bumi (Nadiah, 2013: 505). Peristiwa turunnya hujan tersebut melibatkan adanya perubahan wujud benda, yakni menguap, ketika air laut, sungai, danau menguap terkena sinar matahari, serta mencair yakni ketika awan (campuran debu dan uap air) berubah bentuk menjadi air hujan.

Dr. Wahbah az-Zuhaili (Wahbah az-Zuhaili, 2013: 202) dalam kitab tafsirnya, menafsirkan bahwa ayat di atas berisi perumpamaan-perumpamaan bagi kebenaran dan kebathilan, iman dan kekafiran. Kebenaran yakni Alquran dan iman, adapun kebathilan adalah kekafiran. Perumpamaan kebenaran adalah seperti hujan yang turun dari langit yang mengalir ke lembah-lembah, ada yang deras, dan ada yang tidak deras sesuai dengan kadarnya. Adapun buih air bah yang terangkat di atasnya, seperti kebatilan yang tidak ada manfaatnya.

Perumpamaan kedua, yakni kebenaran seperti tambang yang berguna berupa emas atau perak dan barang tambang lain yang memiliki banyak manfaat. Dan kebathilan adalah noda dan sisa-sia yang tidak berguna yang tersisihkan dari barang tambang jika dilelehkan dengan api. Dengan demikian, yang akan bertahan adalah kebenarandan yang akan sirna adalah kebathilan, seperti halnya buih yang akan tersingkir dan terangkat dari atas air, dan air serta tambang yang berguna akan tetap berada di atas bumi.

Firman Allah dalam surat alWaqi'ah ayat 68-70, yang berbunyi:

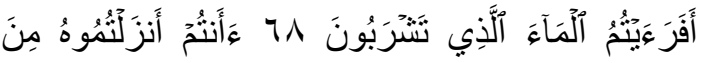

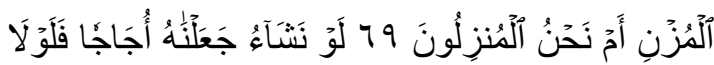

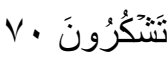

Artinya: Maka terangkanlah kepadaku tentang air yang kamu minum. Kamukah yang menurunkannya atau Kamikah yang menurunkannya. Kalau Kami kehendaki, niscaya Kami jadikan dia asin, maka mengapakah kamu tidak bersyukur. (QS. Al-Waqi'ah: 68-70)

Quraish Shihab (Quraish Shihab, 2002: 373) menafsirkan ayat di atas tentang kuasa Allah dalam menurunkan 
hujan. Allah meminta umatnya agar menjelaskan tentang air apa yang ia minum.Allah yang telah menciptakannya dan telah mengatur prosesnya hingga air tersebut menjadi tawar, dan jika Ia menghendaki air yang turun tersebut rasanya asin atau pahit, sehingga tidak dapat ia minum, maka hendaknya kita sebagai umatnya untuk terus bersyukur kepada Allah yang telah menghendaki air hujan rasanya tawar sehingga dapat diminum.

Kata al-muzn (المزن) adalah bentuk jamak dari kata al-muznah (المزنة), yaitu awan yang mengandung air. Ada juga yang mengartikan awan putih yang mengandung air. Hal ini menunjukkan bahwa tidak semua awan dapat menurunkan hujan, tetapi hanya awan tertentu yang dapat menurunkan hujan. Kata ujaajan (اجاجا) dalam ayat tersebut berarti asin atau pahit yang tidak dapat diminum. Air hujan pada mulanya terasa asin, yakni saat masih menjadi air laut. Zat penyebab rasa asin tersebut telah dihilangkan melalui suatu siklus daur ulang alami yang diciptakan oleh Allah, di mana air laut akan menguap sebagai akibat dari panasnya sinar matahari, kemudian uap air itu diubah menjadi air hujan yang terasa tawar.
Air tawar bergerak dalam atmosfer. Jika ada zat-zat yang mencemarinya, baik berupa karbon monoksida, karbon dioksida, nitrogen, maupun zat-zat pencemar lain, maka ketika air tersebut turun dalam bentuk hujan, ia akan mengalir sekali lagi dalam bentuk asam. Karena, sebagian besar oksida yang mengalir tersebut akan berubah menjadi zat asam yang berdampak pada bebatuan dan makhluk hidup. Hal tersebut membawa pengaruh negatif kepada manusia. Oleh karena itulah, Allah menganugerahkan kepada kita suatu proses yang alamiah, yakni uap air yang berasal dari samudra, lautan, dan daratan, serta melalui proses fotosintesis tumbuhan. Uap air tersebut naik dan menebal, lalu turunlah air hujan yang bersih tersebut. Adapun zat asam yang terbentuk dalam ukuran yang kecil ketika terjadi petir. Merupakan rahmat Allah yang menakdirkan jumlah zat asam tersebut kecil, dan tidak mengganggu kesehatan manusia (Nadiah, 2013: 527528).

Ayat-ayat di atas menunjukkan salah satu contoh wujud benda, yakni cair, dan juga contoh dari perubahan wujud benda, yakni menguap dan mencair. Terdapat juga ayat-ayat yang menjelaskan tentang benda gas, yakni 
tentang angin. Angin merupakan udara yang bergerak, yakni perpindahan udara dari tempat yang bertekanan udara tinggi ke tempat yang bertekanan udara rendah. Angin memiliki ragam dan jenis yang berbeda-beda sesuai dengan kecepatan, kegunaan, dan tujuannya.

Dalam Alquran, kata angin (al-rih atau al-riyah) disebut sebanyak 14 kali dalam 14 surat yang berbeda. Peran angin dalam kehidupan sehari-hari telah berhasil diungkap oleh penelitianpenelitian modern, bahkan sudah dikatakan oleh ayat-ayat Alquran 14 abad yang lalu, jauh sebelum ilmu geologi dan metreorologi menyingkapnya. Firman Allah dalam surat ar-Rum ayat 48:

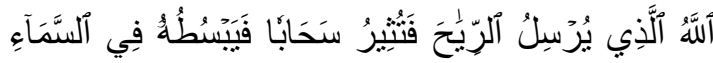

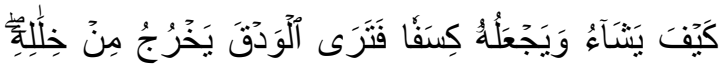

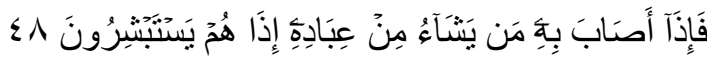
Artinya: Allah, Dialah yang mengirim angin, lalu angin itu menggerakkan awan dan Allah membentangkannya di langit menurut yang dikehendaki-Nya, dan menjadikannya bergumpal-gumpal; lalu kamu lihat hujan keluar dari celahcelahnya, maka apabila Dia mencurahkannya kepada siapa yang Dia kehendaki dari hamba-hamba-Nya, tibatiba mereka menjadi gembira. (QS. ArRum:48)
Quraish Shihab (Quraish Shihab, 2002: 90) menjelaskan ayat di atas mengenai kerja angin dalam konteks hujan, serta proses turunnya hujan tersebut. Ayat di atas menyatakan bahwa Allah yang dari saat ke saat yang mengirim aneka angin, lalu ia yakni angin itu menggerakkan awan dan Allah melalui hukum-hukum alam yang ditetapkan-Nya membentangkannya di langit yakni di awan, sebagaimana yakni dengan cara dan bentuk apapun yang dikehendaki-Nya dan ke lokasi manapunyang ditetapkan-Nya.

Sekali Dia menjadikan awan itu terbentang di langit sedemikian rupa, dan di kali lain Dia menjadikannya bergumpal-gumpal, lalu kamu siapapun kamu melihat hujan keluar dari celahcelahnya awan itu, maka apabila Dia yakni Allah mencurahkannya yakni hujan yang turun atas izin Allah itu kepada siapa yang Dia kehendaki dari hamba-hamba-Nya, tiba-tiba yakni dengan segara dan serta merta begitu hujan turun mereka bergembira.

Hasil peneltian modern menyatakan ada beberapa jenis angin dalam kaitannya dengan awan dan mendung, yakni (Nadiah, 2013: 507):

a. Angin yang tugasnya hanya sebatas merangsang permukaan 
air untuk menciptakan titik-titik air di atas gelombang air.

b. Angin yang bertugas membawa dan mengangkat awan dan uap air ke lapisan atas atmosfer.

c. Angin yang bertugas menuntun dan menjalankan awan, lalu mengakumulasikannya.

d. Angin yang bertugas mengurai awan mendung menjadi hujan dan membaginya ke tempattempat di bumi.

Empat tugas ini menunjukkan jenis angin, rangkaian tugasnya dalam pembentukan awan, dan tahapan-tahapan pembentukannya. Mulai dari merangsang air, membawa awan, mengangkatnya ke lapisan atas atmosfer, menjalankannya dengan lembut, hingga mengatur distribusinya kepada siapa saja yang dikehendaki oleh Allah dalam bentuk hujan. Sebagaimana dalam firman Allah, yang berbunyi:

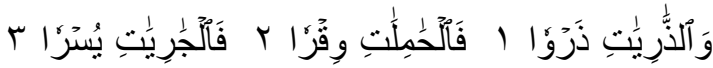

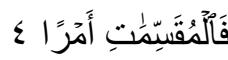

Artinya: Demi (angin) yang menerbangkan debu dengan kuat. Dan awan yang mengandung hujan. Dan kapal-kapal yang berlayar dengan mudah. Dan (malaikat-malaikat) yang membagi-bagi urusan. (QS. AdzDzariyat: 1-4).
Allah bersumpah atas angin yang menerbangkan debu dan merangsang pembentukan titik-titik air, lalu angin yang membawa awan dan uap air menuju ke lapisan atas atmosfer, lalu angin yang menjalankan awan dan mendung dengan penuh kelembutan, dan angin yang membagi-bagikan kuantitas awan dan membaginya ke tempat yang dikehendaki Allah mendapat hujan dan rahmat.

Sebagaimana firman Allah yang berbunyi:

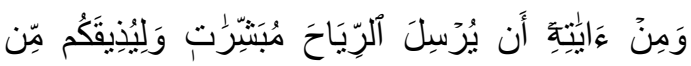

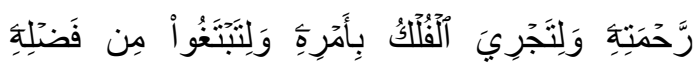

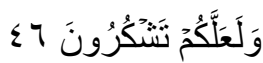

Artinya: Dan di antara tanda-tanda kekuasan-Nya adalah bahwa Dia mengirimkan angin sebagai pembawa berita gembira dan untuk merasakan kepadamu sebagian dari rahmat-Nya dan supaya kapal dapat berlayar dengan perintah-Nya dan (juga) supaya kamu dapat mencari karunia-Nya; mudahmudahn kamu bersyukur. (QS. Ar-Rum: 46)

Quraish Shihab (Quraish Shihab, 2002: 84) menafsirkan ayat di atas seperti menyatakan: Dan di antara tanda-tanda kekuasaan-Nya adalah bahwa Dia senantiasa dan dari saat ke saat mengirimkan aneka angin, ada yang 
berhembus dari selatan, utara, dan lainlain, sebagai pembawa berita gembira tentang bakal turunnya hujan, atau melajunya perahu dan untuk merasakan kepada kamu sebagian dari rahmat-Nya, antara lain dengan hembusannya yang menyegarkan, serta tumbuhnya aneka tumbuhanberkat curahan hujan, dan supaya kapal dapat berlayar dengan perintah-Nya yakni dengan izin-Nya melalui hukum-hukum alam yang telah ditetapkan-Nya dalam konteks angin, laut, serta kapal-kapal dan supaya kamu dapat mencari karunia-Nya dengan berdagang, berpergian untuk berjihad atau menuntut lmu. Itu semua dilakukanNya sebagai anugerah dari-Nya dan agar kamu bersyukur dengan jalan menaati perintah-Nya dan menjauhi laranganNya. Ayat di atas juga menekankan akan nikmat Allah yang dianugerahkan melalui kapal yang mampu mengarungi samudera serta keselamatan selama perjalanan, dan Allah telah menetapkan hukum-hukum alam yang memungkinkan manusia memanfaatkan lautan dengan segala isinya.

Selain hal di atas, konsep mengenai mengapung juga sudah ada sejak dahulu, sebelum ilmu sains menemukan konsep mengenai mengapung atau mengenai prinsip Archimedes tersebut. Konsep mengapung dalam al-Qur'an ditunjukkan dengan adanya ayat al-Qur'an yang menyatakan tentang "kapal yang berlayar”. Kapal tersebut merupakan salah satu contoh dari benda yang dapat mengapung di air. Firman Allah swt. yang berbunyi:

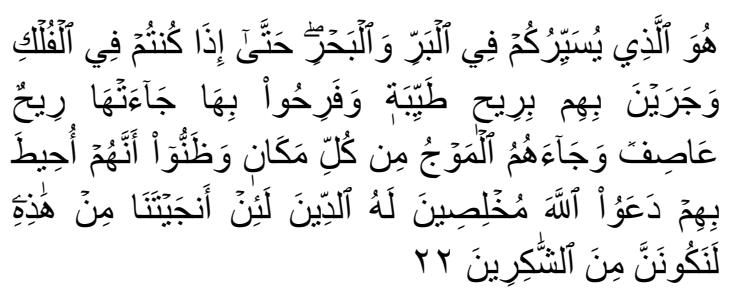

Artinya: Dialah Tuhan yang menjadikan kamu dapat berjalan di daratan, (berlayar) di lautan. Sehingga apabila kamu berada di dalam bahtera, dan meluncurlah bahtera itu membawa orang-orang yang ada di dalamnya dengan tiupan angin yang baik, dan mereka bergembira karenanya, datanglah angin badai, dan (apabila) gelombang dari segenap penjuru menimpanya, dan mereka yakin bahwa mereka telah terkepung (bahaya), maka mereka berdoa kepada Allah dengan mengikhlaskan ketaatan kepada-Nya semata-mata. (Mereka berkata): "Sesungguhnya jika Engkau menyelamatkan kami dari bahaya ini, pastilah kami akan termasuk orangorang yang bersyukur". (QS. Yunus: 22)

Wahbah az-Zuhaili (Wahbah azZuhaili, 2013: 202) menafsirkan ayat di atas sebagai ungkapan sejumlah nikmat yang diberikan oleh Allah kepada manusia. Kemudian melarang umatnya untuk tidak melakukan pengingkaran, 
serta mengancam kesesatan dan perbuatan mereka yang melampaui batas. Di antara nikmat terbesarnya adalah keamanan setelah ketakutan dan keselamatan dari malapetaka setelah mereka mengalaminya. Allah yang membuat manusia mengadakan perjalanan di darat dan di laut dengan sarana-sarana transportasi yang lazim, berupa hewan kendaraan, perahu, mobil, pesawat terbang, dan kereta.

Hal tersebut merupakan nikmat yang besar. Hingga begitu mereka naik perahu layar dan permukaan air oun diterpa tiupan angin yang lembut dan nyaman. Kemudian guncangan demi guncangan terjadi dan bahaya tenggelam pun mereka hadapi lantaran perubahan angin yang bertiup semakin kencang. Angin pun bertiup menjadi badai yang kuat dan penumpang perahu meyakini bahwa mereka akan tenggelam disebabkan angin kencang serta ombak tinggi yang berdeburan dan mengelilingi mereka dari segala arah. Dalam kondisi tersebut, mereka tidak mendapatkan perlindungan kecuali dari Allah. Mereka pun memanjatkan doa kepada-Nya dengan setulus-tulusnya; beribadah dan tunduk kepada-Nya.

\section{Integrasi dalam Konteks Burhani}

Burhani secara bahasa berarti argumentasi yang kuat dan jelas. Pola burhani berangkat dari nalar, dan nalar bermula dari proses abstraksi yang bersifat 'aqly terhadap suatu relaitas sehingga muncul makna, dan makna butuh aktualisasi agar bisa dipahami (Suyudi, 2005: 161). Dengan kata lain, epistimologi burhani bersumber pada realitas alam, sosial, dan budaya. Penulis melakukan observasi di MI Negeri Sukoharjo, dengan melakukan wawancara dengan bu Endang, selaku guru kelas V. Beliau menjelaskan untuk materi wujud benda di kelas $\mathrm{V}$, yakni tentang sifat-sifat benda padat, cair, dan gas, serta adanya perubahan wujud dari benda tersebut.

Integrasi pada konteks burhani juga dilakukan dengan mengaitkan antara realitas alam, sosial, dan budaya. Oleh karena itu, penulis mencoba mengaitkan pembelajaran materi wujud benda denga realitas alam, yakni dengan melakukan kegiatan eksperimen yang nantinya akan dilakukan oleh peserta didik langsung. Peserta didik nantinya akan diminta untuk membuktikan secara langsung terkait materi dari sifat-sifat benda, serta perubahan wujud benda tersebut.

Percobaan tersebut dilakukan secara 
sederhana, mengingat untuk level anak SD kelas V. Misalkan, untuk membuktikan benda cair dapat meresap, maka peserta didik diminta untuk mencelupkan tisu ke dalam air. Percobaan tersebut dapat membuktikan secara langsung bahwa air dapat meresap. Dengan demikian, peserta didik akan melakukan pembelajaran nyata, karena dapat membuktikan sendiri.

Jika dikaitkan dengan realitas alam yang ada di daerah Sukoharjo, di Sukoharjo terdapat banyak persawahan, dan untuk mengairi sawah-sawah tersebut, memanfaatkan salah satu wujud benda, yakni air sungai dan air yang berasal dari sebuah waduk, yakni waduk mulur. Untuk mengetahui adanya wujud benda tersebut, siswa bisa sesekali untuk melakukan melihat-lihat atau berwisata ke waduk atau ke sungai tersebut. Dengan demikian, anak akan lebih mengerti bahwa ternyata wujud benda bisa dijumpai di lingkungan sekitar mereka.

Selain itu, peserta didik juga sesekali perlu diajak untuk melakukan penelitian (melihat secara langsung) mengenai salah satu sifat dari air, yakni memiliki gaya apung ke atas (peristiwa mengapung). Peristiwa tersebut bisa kita lihat di daerah Wonogiri, yang letaknya tidak terlalu jauh dengan Sukoharjo (kurang lebih 45 menit). Di Wonogiri terdapat satu objek wisata yakni waduk gajah mungkur, di mana di waduk tersebut terdapat salah satu sifat air, yakni perahu yang bisa mengapung di atas air. Dengan melihat secara langsung peristiwa tersebut, nantinya siswa akan jauh lebih memahami akan materi yang diajarkan.

Selain itu, perubahan wujud benda yakni menguap jika diintegrasikan ke dalam konteks burhani, yakni dengan realitas alam, yaitu peristiwa terjadinya hujan itu sendiri. Jika air tidak dapat menguap apabila terkena sinar matahari, dan tidak ada angin yang membawa debu, maka tidak akan bisa menjadi hujan, dan jika tidak hujan, maka akan terjadi musim kemarau berkepanjangan.

\section{Integrasi dalam Konteks Irfani}

Integrasi dalam konteks irfani ini yakni mengaitkan suatu ilmu dengan manfaat dari ilmu tersebut. Dalam hal ini, wujud benda akan dikaitkan dengan manfaat setelah mempelajari materi tersebut. Terdapat banyak manfaat ketika mempelajari sifat-sifat benda, perubahan wujud benda dalam kehidupan seharihari. Manfaat mempelajari sifat-sifat benda, baik benda cair, padat, dan gas, yakni: 
a. Air yang dapat mengalir, bermanfaat untuk mengairi sawah. Selain itu, dengan mempelajari sifat air yang dapat mengalir dari tempat yang tinggi menuju tempat yang lebih rendah, menjadikan adanya temuan berupa alat yang mampu membuat air yang awalnya berada di tempat yang lebih rendah, mampu mengalir ke tempat yang lebih tinggi, yakni pompa air. Pompa air mampu membuat air yang berada di dalam tanah menjadi naik ke atas, sehingga air bisa kita gunakan untuk keperluan sehari-hari. Selain itu, alasan tandon air pasti diletakkan di tempat yang tinggi, karena air hanya mampu mengalir dari tempat yang lebih tinggi menuju tempat yang lebih rendah.

b. Air yang dapat menguap jika terkena panas matahari, yakni bermanfaat ketika kita menjamur pakaian, jika terkena sinar matahari air yang ada pada pakaian yang telah kita cuci akan menguap, dan pakaian menjadi kering.

c. Air yang dapat meresap, yakni bermanfaat ketika kita memasak masih menggunakan kompr minyak tanah. Minyak tanah akan naik ke atas sumbu kompor, karena minyak tanah tersebut mampu meresap dengan baik di sumbu kompor. Jika minyak tidak dapat meresap, maka kompor tidak akan dapat menyala.

d. Dengan mempelajari bahwa benda gas dapat menempati wadahnya, yakni kita dapat menggunakan ban sepeda, di mana ban sepeda memanfaatkan gas. Jika gas tidak dapat menempati bentuk ban tersebut, maka ban tidak dapat digunakan.

e. Terdapat banyak manfaat atau kegunaan setelah mempelajari angin, yakni kita dapat memanfaatkan angin untuk membuat kapal layar dapat derlayar di laut. Angin juga bermanfaat untuk membantu proses terjadinya hujan. Angin juga dapat dimanfaatkan untuk bermain layang-layang.

\section{KESIMPULAN}

Integrasi nilai-nilai karakter pada pembelajaran mulai difokuskan sejak diberlakukannya kurikulum 2013. Nilai karakter, salah satunya yaitu nilai religi juga mulai ditekankan pada kurikulum 2013. Implementasi nilai religi dalam pembelajaran dapat dilakukan dengan kegiatan pembelajaran reflektif, yakni 
pengintegrasian nilai tersebut dengan materi-materi pembelajaran umum selama proses kegiatan pembelajaran di kelas. Salah satunya pada pembelajaran sains, yang mana telah diketahui bahwa sains sangat dekat dengan tanda-tanda adanya Allah swt. Sehingga, sudah seharusnya guru memanfaatkan hal tersebut untuk menanamkan nilai-nilai Islam, terlebih sejak anak-anak ada pada usia sekolah dasar.

Integrasi nilai-nilai Islam tersebut dalam kegiatan pembelajaran dapat dilakukan secara bayani, burhani, dan 'irfani. Integrasi dalam konteks bayani berupaya untuk memperjelas, mengungkap, dan menuangkan maksud pembicaraan dengan berdasarkan lafadz. Ciri utamanya adalah menggunakan teks sebagai rujukan pokok sumber pengetahuan. Dalam hal ini, teks yang dimaksud adalah ayat-ayat Alquran. Terdapat banyak ayat yang menjelaskan mengenai sains, dan dalam hal ini sains dan agama bertujuan untuk dapat menghantarkan manusia untuk semakin mengagungkan Allah swt.

Adapun burhani, yaitu argumentasi yang kuat dan jelas. Pola burhani berangkat dari nalar, dan nalar bermula dari proses abstraksi yang bersifat 'aqly terhadap suatu realitas sehingga muncul makna, dan makna butuh aktualisasi agar bisa dipahami. Dengan kata lain, burhani bersumber pada realitas alam, sosial, dan budaya. Integrasi sains dalam konteks burhani, yakni mengintegrasikan materi sains dengan realitas yang ada di alam, lingkungan sosial, dan lingkungan budaya yang ada di daerah masingmasing.

Dalam kehidupan sehari-hari, di lingkungan tempat tinggal kita terdapat banyak penerapan ilmu sains. Misalnya, di lingkungan nelayan, sering dijumpai adanya perahu yang digunakan untuk memancing ikan. Perahu yang mengapung, pada dasarnya menggunakan prinsip dasar fisika, yaitu mengapung. Ketika anak-anak diberi contoh nyata yang ada dalam kehidupan sehari-hari dan ada di lingkungan tempat tinggalnya, maka akan memudahkan anak-anak untuk memahami materi tentang sains, dan ilmu-ilmu lainnya.

Integrasi dalam konteks irfani yakni mengaitkan suatu ilmu dengan manfaat dari ilmu tersebut. Dalam konteks sains, materi sains diintegrasikan dengan manfaat yang ada dalam kehidupan sehari-hari. Terdapat banyak manfaat, khususnya materi sains dalam kehidupan sehar-hari. Sebagai contoh, air yang dapat mengalir, bermanfaat untuk 
mengairi sawah. Selain itu, dengan mempelajari sifat air yang dapat mengalir dari tempat yang tinggi menuju tempat yang lebih rendah, menjadikan adanya temuan berupa alat yang mampu membuat air yang awalnya berada di tempat yang lebih rendah, mampu mengalir ke tempat yang lebih tinggi, yakni pompa air. Pompa air mampu membuat air yang berada di dalam tanah menjadi naik ke atas, sehingga air bisa kita gunakan untuk keperluan sehari-hari. Selain itu, alasan tandon air pasti diletakkan di tempat yang tinggi, karena air hanya mampu mengalir dari tempat yang lebih tinggi menuju tempat yang lebih rendah.

\section{DAFTAR PUSTAKA}

Az-Zuhaili, Wahbah, Tafsir al-Wasith, Vol. 2, Depok: Gema Insani, 2013.

Giancoli, Fisika, terj. Yuhilza Hanum, Jakarta: Penerbit Erlangga, 1999.
Mulyatno, Materi Pokok Fisika Umum, Tangerang Selatan: Universitas Terbuka, 2014.

Saefulloh, Aep, Kumpulan Fakta Sains Unik Dunia, Yogyakarta: Nusa Creativa, 2014

Shihab, Quraish, Tafsir al-Mishbah "Pesan, Kesan, dan Keserasian al-Qur'an”, Vol. 13, Jakarta: Lentera Hati, 2002.

Shihab, Quraish, Tafsir al-Mishbah "Pesan, Kesan, dan Keserasian al-Qur'an", Vol. 11, Jakarta: Lentera Hati, 2002.

Sumarwan, Sumartini, dkk, Science for Junior High School, Jakarta: Penerbit Erlangga, 2010.

Sutarno, Fisika untuk Universitas, Yogyakarta: Graha Ilmu, 2013.

Suyudi, Pendidikan dalam Perspektif alQur'an, Yogyakarta: Mikraj, 2005.

Syakir, Ahmad, Mukhtasar Tafsir Ibnu Katsir, terj. Suratman,Vol. 4, Jakarta Timur: Darus Sunnah Press, 2012.

Thayyarah, Nadiah, Buku Pintar Sains dalam Al-Qur'an: Mengenal Mukjizat Ilmiah Firman Allah, Jakarta: Zaman, 2013.

Tipler, Fisika, terj. Lea Prasetio, Jakarta: Penerbit Erlangga, 1998. 